PRZEGLĄD NAUK HISTORYCZNYCH 2020, R. XIX, NR 2

https://doi.org/10.18778/1644-857X.19.02.01

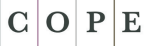

Member since 2018

ŁUKASZ ĆWIKŁa

UNIWERSYTET ŁÓDZKI*

(iD https://orcid.org/0000-0002-3564-7838

\title{
Michał Lasocki (zm. 1472) - konfederat, rycerz, polityk. Przyczynek do badań nad sygnatariuszami konfederacji Spytka z Melsztyna z 1439 roku
}

Streszczenie. Artykuł jest próba wyjścia naprzeciw sformułowanemu przez Franciszka Sikorę postulatowi w sprawie badań karier byłych konfederatów Spytka z Melsztyna z 1439 r. Tytułowy bohater należał do obozu Melsztyńskiego, następnie brał udział w wyprawie węgierskiej Władysława Warneńczyka, a w czasach Kazimierza Jagiellończyka jego kariera polityczna nabrała przyspieszenia. Dzięki przychylności władców otrzymywał zapisy na dobrach monarszych, obją starostwo łęczyckie, sięgnął po urzędy ziemskie, by ostatecznie dostać się na dwór królewski. Będąc marszałkiem nadwornym, wszedł do grona elity politycznej Królestwa.

Słowa kluczowe: Michał Lasocki herbu Dołęga, szlachta, konfederacja Spytka z Melsztyna.

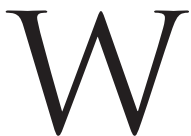

artykule poświęconym badaniom nad sygnatariuszami konfederacji Spytka z Melsztyna z 1439 r. Franciszek Sikora apelował o pełniejsze opracowanie nie tylko zjawiska konfederacji jako takiej, lecz także sylwetek poszczególnych jej uczestników. Argumentował to w sposób następujący: „chodzi tu przede wszystkim o możliwie prawidłowa identyfikację wszystkich osób i miejscowości, z których się one pisały, przynależności rodowej, pokrewieństw i powinowactw, wzajemnych powiązań,

* Wydział Filozoficzno-Historyczny, Instytut Historii, Katedra Historii Średniowiecznej, e-mail: lukasz.cwikla@uni.lodz.pl 
kariery i dalszych losów. Takie opracowanie dostarczy wiele cennego materiału do badań nad konfederacją na wielu płaszczyznach" .

Celem przyczynku jest zatem próba wyjścia naprzeciw sformułowanemu postulatowi i przybliżenie osoby Michała Lasockiego herbu Dołęga (zm. 1472), jednego z sygnatariuszy konfederacji i zięcia Spytka $z$ Melsztyna. To przy okazji także pretekst, aby nieco szerzej zając się tą postacią.

Tytułowy bohater naszych rozważań wywodził się z ziemi dobrzyńskiej, gdzie znajdowało się pierwotne gniazdo Lasockich, czyli Lasotki, zwane w XVI w. również Lasocinem² ${ }^{2}$ Ich zwiazek ze wspomnianym terytorium podkreślił Bartosz Paprocki, który odnotował, że „na ziemi dobrzyńskiej sa Lasotki, z których się pisali, w różnych województwach wielkie majętności mieli”3. Nasz uznany heraldyk miał sporo racji, ponieważ kiedy u schyłku XVI w. oddawał swoje dzieło do druku, familia ta była już znacząca i dobrze rozpoznawana.

Protoplasta Lasockich był Michał, skarbnik dobrzyński w latach 1406-1427 . Nie był to wysoko stojący w hierarchii ziemskiej urząd, ale pozwolił mu wejść do grona lokalnej szlachty urzędniczej. $Z$ małżeństwa $z$ Grzymisławą miał trzech synów: Mikołaja, Jana oraz Jerzego. Pierwszy $z$ wymienionych obrał karierę kościelna i był aktywnym dyplomata ${ }^{5}$. $Z$ kolei Jan obją po ojcu urzad skarbnika (1434), a następnie pełnił funkcję wojskiego (1436-1441) oraz podkomorzego dobrzyńskiego $(1444-1445)^{6}$. Najmłodszy z wymienionych był zaś chorążym większym dobrzyńskim (1436-1466) ${ }^{7}$.

${ }^{1}$ F. Sikora, W sprawie badań nad sygnatariuszami konfederacji Spytka z Melsztyna z 1439 roku, „Studia z Dziejów Średniowiecza” 2016, nr 20, s. 174.

2 A. Bilińs ki, Szlachta ziemi dobrzyńskiej za ostatnich Jagiellonów, Warszawa 1932 , s. 98.

${ }^{3}$ B. Paprocki, Herby rycerstwa polskiego, wyd. K.J. Turowski, Kraków 1858, s. 400 .

${ }^{4}$ Urzędnicy kujawscy i dobrzyńscy XII-XV wieku. Spisy, oprac. J. Bieniak, S. Szybkowski, red. A. Gąsiorowski [dalej: Urz.VI/1], Kórnik 2014, s. 279.

${ }^{5}$ Szerzej na temat Mikołaja por. T. Witczak, Lasocki Mikołaj h. Dołega, [w:] Polski słownik biograficzny [dalej: PSB], t. XVI, Wrocław 1971, s. 542-544; K. Grodziska, Mikołaja Lasockiego obrona pamięci króla Władysława Jagiełły na soborze bazylejskim, [w:] Cracovia. Polonia. Europa. Studia z dziejów średniowiecza ofiarowane Jerzemu Wyrozumskiemu $w$ sześćdziesiata piata rocznice urodzin i czterdziestolecie pracy naukowej, Kraków 1995, s. 345-353.

${ }^{6}$ Urz.VI/ 1, s. 279, 284, 269.

7 Ibidem, s. 256. 
W historiografii panowało do niedawna pewne zamieszanie, jeśli chodzi o prawidłową identyfikację ojca Michała. Feliks Kiryk uznał go błędnie za brata Mikołaja (zm. 1450), dziekana kapituły krakowskiej, biskupa nominata kujawskiego, którego z kolei Tadeusz Witczak i Janusz Bieniak określili jako syna skarbnika dobrzyńskiego Michała i Grzymisławy ${ }^{8}$. Podobne stanowisko w kwestii domniemanego ojca Michała zajęli Jacek Laberschek oraz Sobiesław Szybkowski ${ }^{9}$. W świetle zebranych wywodów interesujacy nas Michał byłby zatem synem skarbnika dobrzyńskiego i Grzymisławy. $Z$ pomoca $w$ prawidłowym określeniu interesującej nas filiacji przyszły dopiero spisy urzędników kujawskich i dobrzyńskich, w których autorzy wykazali, że Michał Lasocki był synem znanego nam już Jana ${ }^{10}$. Wydawcy powołali się na dokument z 10 maja 1444 r., który został wystawiony przez Władysława Warneńczyka na wyspie Csepel ${ }^{11}$. Zgodnie $z$ jego treścią król zapisał Michałowi Lasockiemu 1000 grzywien na zamku i mieście Żydaczowie w województwie ruskim oraz przynależnych do nich wsiach $^{12}$. Interesujaca nas postać została jednak określona jako podkomorzy krakowski. Tymczasem po pierwszy urząd sięgnął on dopiero sześć lat później, o czym szerzej w dalszej części tekstu. Zwróćmy ponadto uwage na to, że nigdy nie wszedł do grona krakowskiej hierarchii ziemskiej. W związku z zasygnalizowanymi wątpliwościami powołajmy się na komentarz autorów przywołanego spisu urzędników. W świetle poczynionych tam ustaleń pierwowzór publikowanego w zbiorze dokumentów małopolskich królewskiego zapisu musiał określać Michała jako podkomorzyca,

${ }^{8}$ F. Kiryk, Lasocki Michał h. Dołega, [w:] PSB, t. XVI, s. 541; T. Witczak, op. cit., s. 542; J. Bieniak, Elita ziemi dobrzyńskiej w późnym średniowieczu $i$ jej majatki, [w:] idem, Polskie rycerstwo średniowieczne. Wybór pism, Kraków 2002, s. 150.

9 J. Laberschek, Uwagi i uzupetnienia do genealogii Melsztyńskich herbu Leliwa, „Średniowiecze Polskie i Powszechne” 2010, t. II (VI), s. 192, przyp. 50; S. Szybkowski, Elita ziemi dobrzyńskiej na przełomie XIV-XV wieku. Między zakonem krzyżackim a Królestwem Polskim, „Średniowiecze Polskie i Powszechne” 2011, t. III (VII), s. 103, przyp. 79.

${ }_{10}$ Urz. VI/1, s. 269.

${ }^{11}$ Król przebywał tam w dniach 10-14 V. Por. S.A. Sroka, W. Zawitkows ka, Itinerarium króla Władysława III 1434-1444, Warszawa 2017, s. 94.

12 Zbiór dokumentów małopolskich [dalej: ZDM], cz. 8, wyd. I. Sułkowska-Kuraś, S. Kuraś, Wrocław 1975, nr 2480. 
ale dobrzyńskiego, co dobrze korespondowałoby z urzędem pełnionym przez jego ojca Jana w tamtym czasie ${ }^{13}$.

Michała Lasockiego poznajemy jako osobę w pełni lat sprawnych w latach trzydziestych XV w. W 1432 r. został on oskarżony o targanie za włosy żupnika krakowskiego Mikołaja Serafina, z którym miał proces o naganę szlachectwa, wygrany zreszta przez tego ostatniego $^{14}$.

W następnych latach Lasocki związał się z obozem politycznym Spytka $z$ Melsztyna, toteż znajdujemy go wśród sygnatariuszy konfederacji zawiąanej 3 maja 1439 r. w Nowym Mieście Korczynie ${ }^{15}$. Jeśli przychylimy się do spostrzeżenia Józefy Olszówki, która stwierdziła, że lista sygnatariuszy została sporządzona w pośpiechu i bez jakiegokolwiek porządku logicznego, a o kształcie listy decydowała kolejność akcesu, to należy odnotować to, że Michał znalazł się na 128 miejscu spośród 164 konfederatów przez nia zidentyfikowanych ${ }^{16}$. Jakkolwiek podkreślmy, że ta ostatnia liczba została zakwestionowana przez F. Sikorę, który po wnikliwej analizie aktu konfederacji doliczył się 170 uczestników ${ }^{17}$. W związku z tym miejsce Lasockiego na liście konfederatów musiałoby ulec drobnemu przesunięciu, choć w konsekwencji nie stanowi to większego znaczenia dla całokształtu ustaleń przedstawionych w tekście.

Wypada w tym miejscu sprostować również drobne pomyłki odnoszące się do interesującej nas postaci. Jerzy Sperka i Bożena Czwojdrak pomyłkowo nazwali Michała Mikołajem, twierdząc, że był on wówczas (w 1439 r.) mężem Doroty Spytkówny ${ }^{18}$. Dodajmy jednak, że w innym miejscu wspomniani badacze prawidłowo

13 Urz. VI/1, s. 269.

${ }^{14}$ F. Kiryk, op. cit., s. 541.

15 Codex epistolaris saeculi decimi quinti [dalej: Cod. epist. saec. XV], t. II, wyd. A. Lewicki, Kraków 1891, nr 255: „Michael de Lasothky”. Szerzej na temat konfederacji Spytka por. A. Sochacka, Konfederacja Spytka z Melsztyna z 1439 r. Rozgrywka polityczna czy ruch ideologiczny?, „Rocznik Lubelski” 1973, t. XVI, s. 41-62; B. Czwojdrak, Kilka uwag o konfederacji Spytka z Melsztyna z 1439 roku, „Średniowiecze Polskie i Powszechne” 2002, t. II, s. 197-211.

16 J. Olszówka, Kilka wniosków ze studium prozopograficznego uczestników konfederacji Spytka z Melsztyna, [w:] Scientia et fidelitate. Ksiega pamiatkowa Ewy i Czesława Deptułów Profesorów Katolickiego Uniwersytetu Lubelskiego, red. T. Panfil, Lublin 2013, s. 740, 754.

17 F. Sikora, op. cit., s. 174 oraz Aneks.

18 J. S perka, B. Czwojdrak, Konfederaci Spytka z Melsztyna z roku 1439, [w:] Król a prawo stanów do oporu, red. M. Markiewicz, E. Opaliński, R. Skowron, Kraków 2010, s. 101. 
podali jego imię ${ }^{19}$. Niemniej jednak małżeństwo z Dorotą zostało zawarte kilka lat po konfederacji, tj. w 1445 r., kiedy Katarzyna, wdowa po Mikołaju z Michałowa, kasztelanie i staroście krakowskim, zapisała swej bratanicy, tj. Dorocie, trzecia część dóbr dziedzicznych w Skorczowie i Radzimicach oraz trzecią część pieniędzy (100 grzywien) $z$ tytułu jej posagu. Ponadto w tym samym roku rajcy miasta Czchowa podarowali sześć achteli piwa i dwa zające warte 8 groszy $z$ okazji małżeństwa panny Melsztyńskiej z Lasockim ${ }^{20}$.

$Z$ powodu braku źródeł nie jesteśmy w stanie odtworzyć szczegółowej działalności Lasockiego jako konfederata. Faktem bezspornym natomiast jest to, że klęska pod Grotnikami i śmierć Spytka 4 maja 1439 r. definitywnie zakończyła dzieje tego swego rodzaju rokoszu. Jak zauważył F. Kiryk, spośród ogólnej liczby konfederatów przeżyło ponad 120, co może świadczyć o tym, że opuścili oni swego przywódcę i to niedługo przed ostateczna potyczką ${ }^{21}$. Wśród nich był także Michał Lasocki, który - jak doskonale wiemy - żył jeszcze długo, a jego kariera - jak się później okazało - potoczyła się dosyć szybko. Niewątpliwy wpływ na jego postawę musiał mieć stryj Mikołaj, wówczas dziekan kielecki, bliski współpracownik Zbigniewa Oleśnickiego ${ }^{22}$. Zdawał on sobie na pewno doskonale sprawę $z$ niebezpieczeństwa, jakie niosła dla bratanka ewentualna zbrojna konfrontacja $z$ oddziałami biskupa krakowskiego. Warto dodać, że w przeddzień bitwy grotnickiej Spytek napadł i ograbił Mikołaja ${ }^{23}$. Fakt ten również chyba nie pozostał bez wpływu na ostateczna decyzję Michała o odstapieniu od Melsztyńskiego.

Po klęsce konfederacji młody Lasocki związał się z obozem królowej Zofii Holszańskiej, a następnie znalazł się w gronie zwolenników króla Władysława. Odnotowujemy go wśród rycerstwa polskiego biorącego udział w wyprawie węgierskiej monarchy. Nie

19 Ibidem, s. 102.

${ }^{20}$ W. Dworzaczek, Leliwici Tarnowscy. Z dziejów możnowładztwa małopolskiego. Wiek XIV-XV, Warszawa 1971, s. 144; F. Kiryk, Melsztyński Spytek h. Leliwa, [w:] PSB, t. XX, Wrocław 1975, s. 417; J. Laberschek, Melsztyn, [w:] Słownik historyczno-geograficzny województwa krakowskiego $w$ średniowieczu [dalej: SHGK], oprac. W. Bukowski, J. Laberschek, A. Marzec, M. Wolski, M. Zdanek, współpraca archeologiczna S. Kołodziejski, red. W. Bukowski, cz. 4, z. 2, Kraków 2009, s. 229; F. Sikor a, op. cit., s. 194.

${ }^{21}$ F. Kiryk, Melsztyński Spytek..., s. 416. Bożena Czwojdrak (op. cit., s. 209-211) zakwestionowała 4 V jako dzień bitwy grotnickiej i jednocześnie datę dzienna śmierci Spytka, przesuwając ją na $6 \mathrm{~V}$.

${ }^{22}$ B. Czwojdrak, op. cit., s. 206, przyp. 34.

${ }^{23}$ T. Witczak, op. cit., s. 543. 
ulega wątpliwości, że Michał był mężnym i sprawnie władającym mieczem rycerzem, gdyż po zwycięskiej wyprawie na Turków i bitwie pod Agrią w 1442 r. władca kazał wymalować 12 herbów panów polskich i węgierskich w kościele parafialnym Najświętszej Marii Panny w Budzie „na znak ich prawości i w nagrodę za ich heroiczne męstwo", wśród których znalazł się herb Dołęga ${ }^{24}$. Na wymierne korzyści nie musiał czekać Michał zbyt długo, gdyż 1 października 1442 r. w Budzie Władysław zapisał mu 200 grzywien na mieście Śrem w powiecie kościańskim ${ }^{25}$. Przypomnijmy w tym miejscu także zapis na Żydaczowie z 10 maja 1444 r., opiewajacy na sumę 1000 grzywien ${ }^{26}$, który stanowi kolejny dowód przychylności monarchy dla Lasockiego, będącego również, a może nawet przede wszystkim, uczestnikiem słynnej bitwy warneńskiej z 10 listopada 1444 r., tak tragicznej w skutkach dla króla Władysława ${ }^{27}$. Niestety, ze względu na brak źródeł, nie jesteśmy w stanie prześledzić szczegółowego udziału Michała w tej batalii. Wiemy natomiast, że udało mu się uniknąć niewoli i powrócić po klęsce do kraju ${ }^{28}$.

Nie można pominąć tego, że w źródłach pisanych Lasocki występował $z$ predykatem strenuus, co oznacza, że dostapił zaszczytu bycia rycerzem pasowanym. W księdze ziemskiej brzezińskiej występował ze wspomnianym określeniem przynajmniej od 1448/1449 r. ${ }^{29}$

${ }^{24}$ J. Długosz, Annales seu Cronicae incliti Regni Poloniae [dalej: JDA], lib. 11-12, Warszawa 2001, s. 288: „Michaelis Lassoczki de armis Dolanga”.

${ }^{25}$ Codex diplomaticus Poloniae [dalej: CDP], t. I, wyd. L. Rzyszczewski, A. Muczkowski, Warszawa 1847, $\mathrm{nr}$ 182; Inventarium omnium et singulorum privilegiorum, litterarum, diplomatum, scriptuarum et monumentorum quaecunque in archivo regni in arce Cracoviensi continentur, wyd. E. Rykaczewski, Paryż 1862, s. 283; Kodeks dyplomatyczny Wielkopolski [dalej: KDW], wyd. A. Gąsiorowski, T. Jasiński, t. X, Poznań 1993, nr 1593. Por. A. Gąs i orowski, Starostowie wielkopolskich miast królewskich $w$ dobie jagiellońskiej, Warszawa-Poznań 1981, s. 64; I. Skiers ka, Śrem - starostwo, [w:] Słownik historyczno-geograficzny województwa poznańskiego w średniowieczu, oprac. P. Dembiński, T. Gidaszewski, K. Górska-Gołaska, T. Jurek, G. Rutkowska, I. Skierska, współpraca archeologiczna Z. Kurnatowska, red. T. Jurek, cz. 5, z. 1, Poznań 2011, s. 83.

${ }^{26}$ Por. przyp. 12.

27 Szerzej na temat bitwy por. K. Olejnik, Bitwa pod Warna, „Balcanica Posnaniensia” 1997, t. VIII, s. 5-15; ide m, Władysław III Warneńczyk (1424-1444), wyd. 2, Kraków 2007, s. 203-223.

${ }^{28}$ Z. Pe n tek, Polscy uczestnicy wyprawy warneńskiej, „Balcanica Posnaniensia” 1997, t. VIII, s. 99.

${ }^{29}$ Archiwum Główne Akt Dawnych w Warszawie [dalej: AGAD], Księgi ziemskie brzezińskie [dalej: KZB], ks. 1-2, k. 396v. Chronologia kart w księdze jest zaburzona. W cytowanej przez nas zapisce strenuus Michał wystapił jako tenutariusz Wiączyna, ale nie został odnotowany z żadnym urzędem, dzięki czemu możemy 
Fakt ten trzeba $z$ cała pewnościa powiązać $z$ zasługami, które wyświadczył królowi i Koronie, szczególnie w okresie wojaczki na Węgrzech. W związku $z$ tym można $z$ dużą doza prawdopodobieństwa zakładać, że Michał uzyskał pas rycerski już wtedy, skoro jego męstwo zostało docenione przez monarchę, a herb wymalowano w kościele.

Skoro watek udziału w konfederacji Spytka $z$ Melsztyna i świetnej karty rycerskiej Lasockiego zostały zasygnalizowane, wypada przejść do omówienia jego kariery politycznej, a także przyjrzeć się sprawom majątkowym, które zajmowały ważne miejsce w jego działalności. Karierę rozpoczął od objęcia starostwa łęczyckiego, które dzierżył zreszta dwukrotnie (1445-1447, 1452-1472)30. Zauważmy, że jego pierwsza nominacja na to starostwo nastapiła w okresie bezkrólewia. Lasocki był więc awansowany przez królewskiego namiestnika w osobie Wojciecha Malskiego. Warto odnotować, że mamy tutaj do czynienia $z$ drugim przypadkiem (po Ostrzeszowie) obsadzenia starostwa przez wicekróla ${ }^{31}$. Według ustaleń Krzysztofa Latochy decyzja ta mogła zapaść w kwietniu 1445 r. na ogólnopolskim zjeździe w Sieradzu ${ }^{32}$. Można zatem wnosić, że nie były to do końca samodzielne decyzje Malskiego i wymagały ostatecznej aprobaty najważniejszych dostojników państwowych. Lasocki przejściowo utracił jednak godność starościńska, co nastapiło najpewniej na przełomie 1447 i 1448 r. ${ }^{33}$ Fakt ten miał związek ze sprawą o zabójstwo. Dnia 28 grudnia 1448 r. Przedbór z Koniecpola, kasztelan sandomierski, Andrzej z Tęczyna, Jan z Tarnowa i Jan z Melsztyna poręczyli za Michała Lasockiego u Jana z Czyżowa,

zawęzić datację tego przekazu źródłowego. Michał pojawił się $z$ tym predykatem również w następującym materiale źródłowym. Por. KZB, ks. 1-2, k. 311, 383v; Księgi ziemskie łęczyckie [dalej: KZŁ], ks. 13, k. 26v, 104v; Księgi grodzkie łęczyckie, ks. 2, k. 84. Problematykę tę omawiaja szerzej: A. Bogucki, Strenuus jako tytut polskich rycerzy pasowanych (XIII-XV w.), „Przegląd Historyczny” 1986, t. LXXVII, z. 4, s. 625-648; A. Szymczakowa, Milites strenui z Sieradzkiego $w X V w$., [w:] Genealogia. Rola zwiazków rodzinnych $i$ rodowych $w$ życiu publicznym $w$ Polsce średniowiecznej na tle porównawczym, red. A. Radzimiński, J. Wroniszewski, Toruń 1966, s. 191-214.

${ }^{30}$ Urzędnicy łęczyccy, sieradzcy i wieluńscy XIII-XV wieku. Spisy, oprac. J. Bieniak, A. Szymczakowa, red. A. Gąsiorowski [dalej: Urz.II/1], Wrocław 1985, s. 88.

${ }^{31}$ Malski przekazał starostwo ostrzeszowskie Janowi Łopacie $z$ Kalinowej, ale decyzja ta została cofnięta przez nowego króla. Por. K. La to cha, Wojciech Malski (ok. 1380-1454) - wojewoda łęczycki i sieradzki oraz namiestnik królewski na Wielkopolske, Warszawa 2015, s. 130.

32 Ibidem, s. 131-132.

${ }^{33}$ Urz.II/ 1, s. 88. 
kasztelana i starosty krakowskiego, że ten po wyjściu z wieży zamku krakowskiego stawi się na sejmie przed majestatem króla. Gdyby zaś tego nie uczynił, będzie musiał zapłacić 2000 grzywien groszy szerokich praskich ${ }^{34}$. Widać zatem ewidentnie, że nie został odwołany przez Kazimierza Jagiellończyka ze starostwa łęczyckiego, co chyba świadczy o wyjątkowej przychylności nowego władcy względem interesujacej nas postaci. W latach 1450-1454 Lasocki pełnił swój pierwszy urząd ziemski, będąc podkomorzym dobrzyńskim ${ }^{35}$. Następnie przeszedł na analogiczną funkcję w ziemi łęczyckiej, sprawując ja w latach 1454-1472 ${ }^{36}$. Podkreślmy za Sobiesławem Szybkowskim, że Michał był osobą zupełnie nową wśród łęczyckiej hierarchii ziemskiej, cieszył się więc ewidentnym poparciem przez króla. Wypada również zgodzić się ze stwierdzeniem wspomnianego badacza, zgodnie $z$ którym Michał „będąc już czas dłuższy łęczyckim starosta (zapewne wtedy nabył też tam dobra dziedziczne) ${ }^{37 "}$. W 1453 r. kupił on za 20 grzywien od Wojciecha z Kozub tamtejsza łąkę. Dokonał również zamiany dóbr $z$ Andrzejem Soczką i jego matką Greta, przekazujac im rzeczona łąkę w zamian za cała wieś Domanikowo, zwana Sitowie, i dopłate 500 grzywien $^{38}$. Transakcje te miały na celu przede wszystkim związanie Lasockiego $z$ województwem łęczyckim, gdyż potencjalne pełnienie urzędu ziemskiego w danym regionie wymagało posiadania miejscowych dóbr (zasada osiadłości) i to właśnie dzięki wspomnianemu zakupowi mógł objąć łęczyckie podkomorstwo. Wymowny jest w tym kontekście fakt, że objął je już w następnym roku. To jednak nie koniec, jeśli chodzi o pełnione przez Michała funkcje i godności. Dostał się on wszakże na dwór królewski, sięgając po urząd marszałka (1462-1472) oraz - jak zostało to odnotowane w spisach urzędni-

${ }^{34}$ Prawo polskie $w$ praktyce sadowej XIV i XV wieku, [w:] Starodawne prawa polskiego pomniki, t. II, wyd. A.Z. Helcel, Kraków 1870, nr 3368.

${ }_{35}$ Urz.VI/1, s. 269.

${ }^{36}$ Urz. II/1, s. 61.

37 S. Szybkowski, Kujawska szlachta urzędnicza w późnym średniowieczu (1370-1501), Gdańsk 2006, s. 199.

38 AGAD, KZ£, ks. 13, k. 66v, 70v. Obie transakcje znajduja się w materiale źródłowym pod tą samą datą, ale należy przyjąć, że Lasocki najpierw kupił łąkę, skoro potem stała się ona przedmiotem zamiany. Natomiast w księdze ziemskiej łęczyckiej wspomniane sprawy zostały odnotowane w odwrotnej kolejności. Por. Ł. Ćwikła, Z ziemi dobrzyńskiej do łęczyckiej. Lasoccy herbu Dołęga $i$ ich majatki $w$ Polsce Centralnej do połowy XVI wieku, [w:] Brzeziny i region. Przeszłość w narracji interdyscyplinarnej. Archeologia - architektura - sztuka-historia, red. L. Tyszler, Brzeziny-Łódź 2019, s. 151 oraz przyp. 18. 
ków centralnych - podskarbiego nadwornego (1467) ${ }^{39}$. Sprawowanie tego ostatniego urzędu przez Lasockiego może budzić jednak pewne wątpliwości, gdyż informacja ta opiera się na błędnie przetłumaczonym dokumencie. Rzekomo 11 czerwca 1467 r. w Nowym Mieście Korczynie król nadał miasteczku Radymno przywilej na jarmark w dzień św. Mateusza. W gronie świadków tego dokumentu został wymieniony Michał Lasocki, którego określono w tłumaczeniu właśnie jako podskarbiego, a następnie wymieniono jego godność starościńską i urząd marszałka. Tymczasem zaszła tutaj ewidentna pomyłka w przekładzie. Oryginalny dokument zawierał po pierwsze, inną datę, która po rozwiązaniu jest 4 czerwca („feria quinta in octava Corporis Christi"). Po drugie, Lasocki widnieje jako świadek $z$ tytulatura podkomorzego i starosty łęczyckiego oraz marszałka nadwornego ${ }^{40}$. Dobrze koresponduje to zatem $z$ praktyką zapisywania tytulatury, gdyż pisarz mógł połączyć podkomorstwo $z$ urzędem starosty i określić je wspólnym przymiotnikiem, odnotowując jako łęczyckie. W wyniku pomyłki z podkomorzego uczyniono więc podskarbiego. Co więcej, Lasocki nie pojawił się na żadnym $z$ dokumentów jako podskarbi, co chyba trudno sobie wyobrazić, gdyby faktycznie nim był. W związku $z$ powyższym, w naszym przekonaniu, Michał nigdy nie sprawował tej funkcji.

Pochylmy się w tym miejscu nad kolejna godnością, czyli urzędem marszałka nadwornego. Zgodnie ze spostrzeżeniami Wojciecha Fałkowskiego wspomniana funkcja - szczególnie w okresie wojny trzynastoletniej - była powierzana, na określony czas lub doraźnie, do wykonania określonej misji ${ }^{41}$. W świetle dotychczasowych ustaleń literatury przedmiotu naszego bohatera odnotowujemy jako marszałka po raz pierwszy pod data 7 czerwca 1462 r. ${ }^{42}$ Należy

39 Urzędnicy centralni i nadworni Polski XIV-XVIII wieku. Spisy, oprac. K. Chłapowski, S. Ciara, Ł. Kądziela, T. Nowakowski, E. Opaliński, G. Rutkowska, T. Zielińska, Kórnik 1992, s. 85, 128.

${ }^{40}$ Akta grodzkie i ziemskie z czasów Rzeczypospolitej Polskiej z Archiwum tak zwanego bernardyńskiego we Lwowie [dalej: AGZ], wyd. K. Liske, t. VIII, Lwów 1880, nr 97: „et Michaele Lassothsky Succamerario et Capitaneo Laciciensi et Curie nostre Marschalcis". Por. AGZ, t. VII, s. 31. Por. G. Ru tk ow s ka, Itinerarium króla Kazimierza Jagiellończyka 1440-1492, Warszawa 2014, s. 214, przyp. 1107.

${ }^{41}$ W. Fałkow ski, Elita władzy w Polsce za panowania Kazimierza Jagiellończyka (1447-1492). Studium aspektów politycznych, Warszawa 1992, s. 142.

42 Urzędnicy centralni..., s. 85. Wydawcy katalogu dokumentów i listów królewskich pomyłkowo przypisali mu sprawowanie funkcji marszałka od $1464 \mathrm{r}$. Por. Katalog dokumentów i listów królów polskich $z$ Archiwum Państwowego 
jednak ją przesunąć, gdyż widzimy go w tej roli już 7 lipca $1461 \mathrm{r}$. oraz 14 lutego 1462 r. $^{43}$ Jeszcze w tym samym roku, tj. 22 sierpnia 1462 r., wystapił ze wspomniana godnościa w formule testacyjnej dokumentu Kazimierza Jagiellończyka, w którym władca wydzierżawił na jeden rok za 16000 grzywien Jerzemu i Magdalenie Morsztynom, mieszczanom krakowskim, żupy solne krakowskie w Bochni, Wieliczce i ruskie, w szczególności przemyskie ze Słoniem, samborskie $z$ Jasienica i sanockie $z$ Żyrawa na takich samych zasadach, na jakich trzymali je ich poprzednicy: Piotr Pikaran, Abraham Czarny, Antoni z Florencji, Mikołaj z Tarnawy i Mikołaj Serafin ${ }^{44}$. Z kolei 22 lipca 1463 r. stanowisko marszałka piastował Piotr Dunin (ostatni raz w tej roli), w 1464 r. ponownie Lasocki $\mathrm{i}$ w roku następnym $z$ data dzienna 25 czerwca $^{45}$. Dnia 4 czerwca 1467 r. Michał ponownie był już marszałkiem dworu ${ }^{46}$. Także cztery lata później, tj. 25 czerwca 1471 r., kiedy świadkował w dokumencie Kazimierza Jagiellończyka, który na prośbę swego dworzanina Stanisława Lanckorońskiego $z$ Lanckorony i Brzezia przeniósł na prawo magdeburskie jego wsie w powiecie i ziemi krakowskiej, tj. Brzezie, Szarów, Dąbrowę, Łysokanie, Grodkowice i Zborczyce ${ }^{47}$. Natomiast 9 sierpnia tego samego roku nie zostal odnotowany $z$ godnościa marszałka ${ }^{48}$. Chyba po raz ostatni pełnił tę funkcję 25 marca $1472 \mathrm{r} .{ }^{49} \mathrm{Na}$ podstawie przywołanych informa-

w Gdańsku (do 1492 roku), oprac. M. Grulkowski, B. Możejko, S. Szybkowski, Gdańsk 2014, s. 60, przyp. 26.

${ }^{43}$ AGAD, KZ£, ks. 2, k. 268v, 270. Za wskazanie tych zapisek dziękuję Panu Profesorowi Tadeuszowi Nowakowi.

${ }^{44}$ Materiały do Kodeksu Dyplomatycznego Małopolski, t. V (1451-1506), edycja elektroniczna, oprac. W. Bukowski, F. Sikora, J. Wroniszewski, red. W. Bukowski, przy współpracy J. Szyszki, nr 545, http://www.kodeks.pau.krakow.pl/ dokumenty.html (dostęp: 20 I 2020).

45 Zbiór dyplomów klasztoru mogilskiego przy Krakowie, wyd. E. Janota, Kraków 1865, nr 142: „Praesentibus [...] Petro Dunin de Prawkovicze [...] curiae nostrae marschalco"; Codex diplomaticus Universitatis Studii Generalis Cracoviensis, wyd. Ż. Pauli, cz. 2, Kraków 1873, nr 213: „Michael Laszoczsky Succamerarius et Capitaneus Lanciciensis nec non Marsalcus curiae regalis”. Por. W. Fałkowski, op. cit., s. 142 .

46 AGZ, t. VIII, nr 97.

${ }^{47}$ Materiały do Kodeksu..., nr 962, http://www.kodeks.pau.krakow.pl/dokumenty.html (dostęp: 20 I 2020).

${ }^{48}$ Matricularum Regni Poloniae summaria, excussis codicibus, qui in Chartophylacio Maximo Varsoviensi asservantur [dalej: MRPS], wyd. T. Wierzbowski, cz. 2, Warszawa 1905, nr 88 (Suplement).

49 AGAD, Metryka Koronna, ks. 12, k. 68v; Urzędnicy centralni..., s. 85. 
cji można zauważyć, że od ostatniego wystąpienia Piotra Dunina jako marszałka widzimy na tym stanowisku już tylko Lasockiego, gdyż nie zostały poświadczone źródłowo inne osoby piastujące wspomniana godność. Nasuwa się zatem wniosek, że od tego czasu mamy do czynienia $z$ pewna stabilizacja, jeśli chodzi o ten urząd $^{50}$.

Jak już wspomniano, Lasocki budował zaplecze ziemskie w północnej części województwa łęczyckiego. Wracając zatem do wątku majątkowego, powołajmy się na zapis z 13 kwietnia $1463 \mathrm{r}$. Przebywający wówczas w Łęczycy król stwierdził, że Michał z Lasotek, podkomorzy i starosta łęczycki, sprzedał Sitowie, Domanikowo Małe, Kopyta, Czyste i Jankowice w powiecie łęczyckim Klemensowi ze Straszkowa Małego, chorążemu mniejszemu łęczyckiemu, wraz z domem w Łęczycy za kwotę 300 grzywien ${ }^{51}$. Sprzedaż tych dóbr zwiazana była zapewne $z$ transakcja przeprowadzona rok wcześniej, gdy Michał kupił Brzeziny, które od tej pory stały się główna siedziba nie tylko jego, lecz także kolejnych pokoleń tej rodziny ${ }^{52}$.

Lasocki dysponował również dobrami w Małopolsce. W $1445 \mathrm{r}$. Marek $z$ Minogi skwitował Michała ze spłaty 150 florenów długu i ustapił mu wsie Rudnik (Rudniki w powiecie lelowskim?) i Rodaki ${ }^{53}$, które trzymał tytułem zastawu we wspomnianej sumie ${ }^{54}$. Z kolei w 1453 r. nabył on od Andrzeja Tęczyńskiego części w Skorczowie i Radzimicach za 600 grzywien $^{55}$.

Nie ulega wątpliwości, że to właśnie zapisy na królewszczyznach (aneks 1) i pełnienie rozmaitych urzędów przyczyniły się do pomno-

50 Urzędnicy centralni..., s. 85 i n.

${ }^{51}$ Ł. Ćwikła, op. cit., s. 151.

52 Szerzej na temat szczegółów zwiąanych z zakupem Brzezin por. T. N ow ak, R. Rosin, H. Wiklak, Brzeziny i okolice do schyłku XVI w., [w:] Brzeziny. Dzieje miasta do 1995 roku, red. K. Badziak, Łódź-Brzeziny 1997, s. 49; A. Szy m czakow a, Szlachta sieradzka w XV wieku. Magnifici et generosi, Łódź 1998, s. 128; S. Szybkowski, Studia z genealogii i prozopografii polskiej szlachty późnośredniowiecznej, Gdańsk 2003, s. 85; Ł. Ćwikła, op. cit., s. 152-153.

53 Być może chodzi tutaj o wieś Rodaki (Rodaków), znajdująca się w powiecie proszowickim, w parafii Chechło. Por. Atlas historyczny Polski. Województwo krakowskie $w$ drugiej połowie XVI wieku, oprac. K. Chłapowski, J. Duma, K. Follprecht, J. Laberschek, Z. Noga, M. Piber-Zbieranowska, Z. Piech, E. Rutkowska, H. Rutkowski, R. Skowron, J. Supruniuk, M. Wilska, M. Zbieranowski, red. H. Rutkowski, cz. 2 (Komentarz, indeksy), Warszawa 2008, s. 276.

${ }^{54}$ M. Zdanek, Minoga, [w:] SHGK, cz. 4, z. 3, s. 488.

55 J. Kurtyka, Tęczyńscy. Studium $z$ dziejów polskiej elity możnowładczej $w$ średniowieczu, Kraków 1997 (reprint: Kraków 2017), s. 476. 
żenia możliwości finansowych Michała, co zawdzięczał przychylności kolejnych władców, w szczególności króla Kazimierza, za panowania którego wielu byłych konfederatów zrobiło znaczące kariery ${ }^{56}$.

Podkreślmy, że Lasocki zaliczał się do grona ważnych dostojników Królestwa. Dość powiedzieć, że znajdujemy jego nazwisko na akcie inkorporacji Prus do Korony 6 marca 1454 r. ${ }^{57}$ Warto dodać, że w dokumencie tym po raz pierwszy został odnotowany jako podkomorzy łęczycki. Michał przebywał wówczas w Krakowie, uzyskując nominację na wspomniany urząd. Wymowny jest również fakt, że znalazł się wśród gwarantów drugiego pokoju toruńskiego $^{58}$. Spotykamy go także - co już zasygnalizowano - jako świadka w dokumentach królewskich. Zgodnie $z$ ustaleniami W. Fałkowskiego Michał w latach 1454-1466 występował 24 razy w formule testacyjnej dokumentów Kazimierza Jagiellończyka, a od 1466 r. aż do swojej śmierci w 1472 r. - 15 razy $^{59}$. Spotykamy go więc często u boku monarchy, któremu towarzyszył w rozmaitych przedsięwzięciach. Przywołajmy zatem kilka przykładów aktywności politycznej naszego bohatera. Brał udział w sejmie w Piotrkowie 17 czerwca 1451 r. ${ }^{60}$ Dnia 27 czerwca 1455 r. również był obecny w Piotrkowie na sejmie, kiedy król Kazimierz Jagiellończyk potwierdził nadania swych przodków dla mieszkańców Królestwa Polskiego $^{61}$. Następnie 9 października 1457 r. widzimy go w Kole, gdy Kazimierz Jagiellończyk potwierdził zwolnienia synów Marcisza $z$ Morawska od służby lennej, do jakiej tytułem posiadania wsi Morawska i przyległości byli zobowiązani Janowi Jarosławskie$\mathrm{mu}^{62}$. Dnia 28 kwietnia 1458 r. Lasocki przebywał w Piotrkowie

56 W. Fałkowski, op. cit., s. 62-63.

57 Volumina legum. Przedruk zbioru praw staraniem XX. Pijarów w Warszawie, od roku 1732 do roku 1782, wydanego, wyd. J. Ohryzko, t. I, Petersburg 1859, s. 81; Knigi polskoj koronnoj metriki XV stoletija. Matricularum Regni Poloniae codices saeculo XV conscripti, wyd. A. Mysłowski, W. Graniczny, t. I, Warszawa 1914, nr 227.

58 M. Grzegorz, Analiza dyplomatyczno-sfragistyczna dokumentów traktatu toruńskiego 1466 r., Toruń 1970, s. 215; A. G a s i or ow s ki, Polscy gwaranci traktatów z Krzyżakami XIV-XV wieku, „Komunikaty Mazursko-Warmińskie” 1971, nr 2-3, s. 263.

59 W. Fałkowski, op. cit., s. 87, tabela V; s. 122, tabela IX.

60 Volumina legum..., s. 77.

61 AGZ, t. V, s. 183-184.

${ }^{62}$ Cod. epist. saec. XV, t. III, nr 78. 
na sejmie. Wówczas król, na prośbę opata sulejowskiego, nadał miastu Sulejów prawo odbywania targów w trzech terminach: Podwyższenia Krzyża (14 września), św. Jana Chrzciciela (24 czerwca), św. Leonarda (6 listopada) i przyznał wspomnianym targom takie same warunki, jakie obowiazywały w Piotrkowie ${ }^{63}$. Był $z$ władca w Krakowie 15 czerwca 1464 r. Kazimierz Jagiellończyk włączył wtedy $z$ powrotem do dóbr królewskich wsie Zielonki i Marszowice $z$ folwarkami i trzema młynami, które stanowiły część uposażenia kaplicy św. Trójcy w katedrze krakowskiej, ufundowanej przez jego matkę, królową Zofię. Król dał w zamian kaplicy 100 grzywien i 8 ćwiertni soli rocznie żup bocheńsko-wielickich ${ }^{64}$. Był ponadto u boku monarchy we Lwowie 23 sierpnia 1470 r. Kazimierz Jagiellończyk ustanowił wówczas w mieście arcybiskupim Dunajowie dwa jarmarki doroczne na św. Piotra w okowach i drugi na św. Jadwige oraz targi tygodniowe ${ }^{65}$. Dnia 20 listopada $1470 \mathrm{r}$. odnotowujemy Michała po raz już kolejny na sejmie piotrkowskim. Wtedy to Kazimierz Jagiellończyk poręczył, że pomoc pieniężna dana na potrzeby Królestwa przez stany polskie nie uwłacza ich wolnościom i prawom, które zarazem ponownie potwierdził ${ }^{66}$. Sa to - co oczywiste - tylko wybrane przejawy działalności politycznej interesującej nas postaci, ale udowadniaja, że była to osoba blisko współpracujacca $z$ monarchą, która często angażowała się w bieżące sprawy Królestwa.

Michał brał także aktywny udział w życiu politycznym ziemi łęczyckiej, co wynikało przede wszystkim $z$ pełnionych przez niego funkcji. Widzimy go w Łęczycy 12 września 1447 r. Zauważmy jednak, że w opublikowanej przez Adolfa Pawińskiego sprawie brakuje terminu convencio, co powoduje w konsekwencji, że trudno przypisać mu w tym wypadku udział w sejmiku łęczyckim ${ }^{67}$. Podobne watpliwości budzi zapiska opatrzona data 3 kwietnia 1455 r. Przebywający wówczas w Łęczycy dostojnicy, wśród których znaj-

${ }^{63}$ Materiały do Kodeksu..., nr 316, http://www.kodeks.pau.krakow.pl/dokumenty.html (dostęp: 20 I 2020).

${ }^{64}$ Ibidem, nr 636, http://www.kodeks.pau.krakow.pl/dokumenty.html (dostęp: 20 I 2020).

${ }^{65}$ AGZ, t. II, s. 203-205.

${ }^{66}$ Cod. epist. saec. XV, t. III, nr 121.

67 A. Pawiński, Sejmiki ziemskie. Początek ich i rozwój aż do ustalenia się udziału posłów ziemskich w ustawodawstwie sejmu walnego 1374-1505, Warszawa 1895, Dodatki nr 19. 
dował się Lasocki, sami przyznali, że ich zgromadzenia nie można uznać za sejmik ${ }^{68}$. Sejmik łęczycki, na którym obecny był Michał, odbył się natomiast 28 kwietnia $1455 \mathrm{r} \cdot{ }^{69}$ Dnia 10 sierpnia $1459 \mathrm{r}$. był ponadto obecny w Łęczycy w czasie pobytu w niej Kazimierza Jagiellończyka ${ }^{70}$. Zgodnie $z$ przekazem Jana Długosza w 1466 r. Michał $z$ wojewoda sieradzkim Sędziwojem $z$ Leżenic przebywali trzy dni w Łęczycy (począwszy od 20 stycznia) jako królewscy wysłannicy i domagali się, aby udzielić pomocy monarsze w postaci gotówki od diecezji gnieźnieńskiej, włocławskiej i poznańskiej po wiardunku od grzywny, a od biskupa i kleru krakowskiego w wysokości 6 groszy od grzywny ${ }^{71}$.

W świetle powyższych rozważań ewidentnie widać, że Michał Lasocki przeszedł bardzo ciekawa, ale zarazem dosyć trudną drogę, zanim został liczącym się dostojnikiem państwowym, biorącym udział w życiu politycznym ziemi łęczyckiej i Królestwa Polskiego. Poznajemy go wszakże jako awanturnika, by przypomnieć w tym miejscu epizod $z$ Mikołajem Serafinem, następnie jako konfederata Spytka, wreszcie walczącego na Węgrzech rycerza i siedzącego w wieży zabójcę. Wydaje się, że mógł sporo zawdzięczać swojemu stryjowi Mikołajowi, przynajmniej w początkowej fazie drogi na przysłowiowy szczyt. Jakkolwiek faktem jest, że wielu byłych konfederatów - co już zasygnalizowano - zrobiło znaczace kariery w czasach Kazimierza Jagiellończyka. Warto w tym miejscu przywołać opinię W. Fałkowskiego, który skonkludował, że „ich obecność przy królu w tych latach oraz późniejsze awanse nie wynikały jedynie $z$ faktu opowiedzenia się kiedyś przeciwko Oleśnickiemu, lecz także $z$ ich zdolności i zasług"72. Zatem dalsze sukcesy Michała były zapewne rezultatem jego osobistych cech, co $z$ pewnościa musiało budzić uznanie, najpierw Władysława, a później Kazimierza, gdyż bez ich dobrej woli tak wspaniała kariera nie byłaby prze-

68 Ibidem, nr 23: „et alii quam plures terrigene connotati, per dominum capitaneum notare mandaverunt, quia eandem congregacionem seu convencionem non habent neque habere volunt pro convencione terrestri”.

${ }^{69}$ Ibidem, nr 24: „Actum Lancicie feria secunda ipso die sancti Vitalis in convencione terrestri".

70 Ibidem, $\mathrm{nr}$ 26: „Actum in Lancicia feria sexta in festo sancti Laurencii martiris tempore stacionis domini Regis anno Domini MCCCCL nono". Por. G. Rutkowska, op. cit., s. 172: informacja o pobycie Kazimierza w Łęczycy w dniach 18-30 VIII.

${ }^{71}$ JDA, lib. 12, s. 125.

${ }^{72}$ W. Fałkowski, op. cit., s. 62. 
cież możliwa. Zmarły w 1472 r. Lasocki pozostawił solidne zaplecze majątkowe dla kolejnych pokoleń swojej rodziny (aneks 2), która za jego sprawa trwale związała się $z$ województwem łęczyckim, przede wszystkim $z$ Brzezinami.

\section{Bibliografia}

\section{$\dot{Z}_{\text {RÓDEA ARCHIWALNE }}$}

Archiwum Główne Akt Dawnych w Warszawie [AGAD]

Księgi grodzkie łęczyckie, ks. 2.

Księgi ziemskie brzezińskie [KZB], ks. 1-2.

Księgi ziemskie łęczyckie [KZ€], ks. 2, 13.

Metryka Koronna, ks. 12.

\section{ŹRÓDEA DRUKOWANE}

Akta grodzkie i ziemskie z czasów Rzeczypospolitej Polskiej z Archiwum tak zwanego bernardyńskiego we Lwowie, wyd. K. Liske, t. II, Lwów 1870.

Akta grodzkie i ziemskie z czasów Rzeczypospolitej Polskiej z Archiwum tak zwanego bernardyńskiego we Lwowie, wyd. K. Liske, t. V, Lwów 1875.

Akta grodzkie i ziemskie z czasów Rzeczypospolitej Polskiej z Archiwum tak zwanego bernardyńskiego we Lwowie, wyd. K. Liske, t. VII, Lwów 1878.

Akta grodzkie i ziemskie z czasów Rzeczypospolitej Polskiej z Archiwum tak zwanego bernardyńskiego we Lwowie, wyd. K. Liske, t. VIII, Lwów 1880.

Codex diplomaticus Poloniae, t. I, wyd. L. Rzyszczewski, A. Muczkowski, Warszawa 1847.

Codex diplomaticus Universitatis Studii Generalis Cracoviensis, wyd. Ż. Pauli, cz. 2, Kraków 1873.

Codex epistolaris saeculi decimi quinti, t. II, wyd. A. Lewicki, Kraków 1891.

Długosz J., Annales seu Cronicae incliti Regni Poloniae, lib. 11-12, Warszawa 2001.

Długosz J., Annales seu Cronicae incliti Regni Poloniae, lib. 12, Kraków 2005.

Inventarium omnium et singulorum privilegiorum, litterarum, diplomatum, scriptuarum et monumentorum quaecunque in archivo regni in arce Cracoviensi continentur, wyd. E. Rykaczewski, Paryż 1862.

Katalog dokumentów i listów królów polskich z Archiwum Państwowego w Gdańsku (do 1492 roku), oprac. M. Grulkowski, B. Możejko, S. Szybkowski, Gdańsk 2014.

Knigi polskoj koronnoj metriki XV stoletija. Matricularum Regni Poloniae codices saeculo XV conscripti, wyd. A. Mysłowski, W. Graniczny, t. I, Warszawa 1914.

Kodeks dyplomatyczny Wielkopolski, wyd. A. Gąsiorowski, T. Jasiński, t. X, Poznań 1993. 
Matricularum Regni Poloniae summaria, excussis codicibus, qui in Chartophylacio Maximo Varsoviensi asservantur, wyd. T. Wierzbowski, cz. 1-2, Warszawa 1905-1907.

Paprocki B., Herby rycerstwa polskiego, wyd. K.J. Turowski, Kraków 1858.

Prawo polskie w praktyce sadowej XIV i XV wieku, [w:] Starodawne prawa polskiego pomniki, t. II, wyd. A.Z. Helcel, Kraków 1870.

Volumina legum. Przedruk zbioru praw staraniem XX. Pijarów $w$ Warszawie, od roku 1732 do roku 1782, wydanego, wyd. J. Ohryzko, t. I, Petersburg 1859.

Zbiór dokumentów małopolskich, cz. 8, wyd. I. Sułkowska-Kuraś, S. Kuraś, Wrocław 1975.

Zbiór dyplomów klasztoru mogilskiego przy Krakowie, wyd. E. Janota, Kraków 1865.

\section{Opracowania}

Atlas historyczny Polski. Województwo krakowskie w drugiej połowie XVI wieku, oprac. K. Chłapowski, J. Duma, K. Follprecht, J. Laberschek, Z. Noga, M. Piber-Zbieranowska, Z. Piech, E. Rutkowska, H. Rutkowski, R. Skowron, J. Supruniuk, M. Wilska, M. Zbieranowski, red. H. Rutkowski, cz. 2 (Komentarz, indeksy), Warszawa 2008.

Bieniak J., Elita ziemi dobrzyńskiej w późnym średniowieczu i jej majątki, [w:] J. Bieniak, Polskie rycerstwo średniowieczne. Wybór pism, Kraków 2002, s. 131-171.

Biliński A., Szlachta ziemi dobrzyńskiej za ostatnich Jagiellonów, Warszawa 1932.

Bogucki A., Strenuus jako tytuł polskich rycerzy pasowanych (XIII-XV w.), „Przegląd Historyczny" 1986, t. LXXVII, z. 4, s. 625-648.

Czwojdrak B., Kilka uwag o konfederacji Spytka z Melsztyna z 1439 roku, „Średniowiecze Polskie i Powszechne" 2002, t. II, s. 197-211.

Ćwikła Ł., Z ziemi dobrzyńskiej do łęczyckiej. Lasoccy herbu Dołega i ich majątki w Polsce Centralnej do połowy XVI wieku, [w:] Brzeziny i region. Przeszłość $w$ narracji interdyscyplinarnej. Archeologia - architektura - sztuka - historia, red. L. Tyszler, Brzeziny-Łódź 2019, s. 149-157.

Dworzaczek W., Leliwici Tarnowscy. Z dziejów możnowładztwa małopolskiego. Wiek XIV-XV, Warszawa 1971.

Fałkowski W., Elita władzy w Polsce za panowania Kazimierza Jagiellończyka (1447-1492). Studium aspektów politycznych, Warszawa 1992.

Gąsiorowski A., Polscy gwaranci traktatów z Krzyżakami XIV-XV wieku, „Komunikaty Mazursko-Warmińskie" 1971, nr 2-3, s. 245-265.

Gąsiorowski A., Starostowie wielkopolskich miast królewskich $w$ dobie jagiellońskiej, Warszawa-Poznań 1981.

Grodziska K., Mikołaja Lasockiego obrona pamięci króla Władysława Jagiełły na soborze bazylejskim, [w:] Cracovia. Polonia. Europa. Studia z dziejów średniowiecza ofiarowane Jerzemu Wyrozumskiemu w sześćdziesiata piąta rocznice urodzin i czterdziestolecie pracy naukowej, Kraków 1995, s. 345-353.

Grzegorz M., Analiza dyplomatyczno-sfragistyczna dokumentów traktatu toruńskiego 1466 r., Toruń 1970. 
Kiryk F., Lasocki Michał h. Dołęga, [w:] Polski słownik biograficzny, t. XVI, Wrocław 1971, s. 541-542.

Kiryk F., Melsztyński Spytek h. Leliwa, [w:] Polski słownik biograficzny, t. XX, Wrocław 1975, s. 415-417.

Kurtyka J., Tęczyńscy. Studium z dziejów polskiej elity możnowładczej w średniowieczu, Kraków 1997 (reprint: Kraków 2017).

Laberschek J., Uwagi i uzupełnienia do genealogii Melsztyńskich herbu Leliwa, „Średniowiecze Polskie i Powszechne” 2010, t. II (VI), s. 180-198.

Laberschek J., Melsztyn, [w:] Słownik historyczno-geograficzny województwa krakowskiego $w$ średniowieczu, oprac. W. Bukowski, J. Laberschek, A. Marzec, M. Wolski, M. Zdanek, współpraca archeologiczna S. Kołodziejski, red. W. Bukowski, cz. 4, z. 2, Kraków 2009, s. 209-268.

Latocha K., Wojciech Malski (ok. 1380-1454) - wojewoda łęczycki i sieradzki oraz namiestnik królewski na Wielkopolskę, Warszawa 2015.

Nowak T., Rosin R., Wiklak H., Brzeziny i okolice do schyłku XVI w., [w:] Brzeziny. Dzieje miasta do 1995 roku, red. K. Badziak, Łódź-Brzeziny 1997, s. 41-74.

Olejnik K., Bitwa pod Warna, „Balcanica Posnaniensia” 1997, t. VIII, s. 5-15.

Olejnik K., Władysław III Warneńczyk (1424-1444), wyd. 2, Kraków 2007.

Olszówka J., Kilka wniosków ze studium prozopograficznego uczestników konfederacji Spytka z Melsztyna, [w:] Scientia et fidelitate. Ksiega pamiatkowa Ewy i Czesława Deptułów Profesorów Katolickiego Uniwersytetu Lubelskiego, red. T. Panfil, Lublin 2013, s. 737-754.

Pawiński A., Sejmiki ziemskie. Początek ich i rozwój aż do ustalenia się udziału posłów ziemskich w ustawodawstwie sejmu walnego 1374-1505, Warszawa 1895.

Pentek Z., Polscy uczestnicy wyprawy warneńskiej, „Balcanica Posnaniensia” 1997, t. VIII, s. 93-108.

Rutkowska G., Itinerarium króla Kazimierza Jagiellończyka 1440-1492, Warszawa 2014.

Sikora F., W sprawie badań nad sygnatariuszami konfederacji Spytka z Melsztyna z 1439 roku, „Studia z Dziejów Średniowiecza” 2016, nr 20, s. 171-201.

Skierska I., Śrem-starostwo, [w:] Słownik historyczno-geograficzny województwa poznańskiego $w$ średniowieczu, oprac. P. Dembiński, T. Gidaszewski, K. Górska-Gołaska, T. Jurek, G. Rutkowska, I. Skierska, współpraca archeologiczna Z. Kurnatowska, red. T. Jurek, cz. 5, z. 1, Poznań 2011, s. 83-85.

Sochacka A., Konfederacja Spytka z Melsztyna z 1439 r. Rozgrywka polityczna czy ruch ideologiczny?, „Rocznik Lubelski” 1973, t. XVI, s. 41-62.

Sperka J., Czwojdrak B., Konfederaci Spytka z Melsztyna z roku 1439, [w:] Król a prawo stanów do oporu, red. M. Markiewicz, E. Opaliński, R. Skowron, Kraków 2010, s. 89-104.

Sroka S.A., Zawitkowska W., Itinerarium króla Władysława III 1434-1444, Warszawa 2017.

Szybkowski S., Elita ziemi dobrzyńskiej na przełomie XIV-XV wieku. Między zakonem krzyżackim a Królestwem Polskim, „Średniowiecze Polskie i Powszechne” 2011 , t. III (VII), s. 87-119. 
Szybkowski S., Kujawska szlachta urzędnicza w późnym średniowieczu (1370 1501), Gdańsk 2006.

Szybkowski S., Studia z genealogii i prozopografii polskiej szlachty późnośredniowiecznej, Gdańsk 2003.

Szymczakowa A., Milites strenui z Sieradzkiego w XV w., [w:] Genealogia. Rola zwiazków rodzinnych $i$ rodowych $w$ życiu publicznym $w$ Polsce średniowiecznej na tle porównawczym, red. A. Radzimiński, J. Wroniszewski, Torun 1966, s. $191-214$.

Szymczakowa A., Szlachta sieradzka w XV wieku. Magnifici et generosi, Łódź 1998.

Urzędnicy centralni i nadworni Polski XIV-XVIII wieku. Spisy, oprac. K. Chłapowski, S. Ciara, Ł. Kądziela, T. Nowakowski, E. Opaliński, G. Rutkowska, T. Zielińska, Kórnik 1992.

Urzędnicy kujawscy i dobrzyńscy XII-XV wieku. Spisy, oprac. J. Bieniak, S. Szybkowski, red. A. Gąsiorowski, Kórnik 2014.

Urzędnicy łęczyccy, sieradzcy i wieluńscy XIII-XV wieku. Spisy, oprac. J. Bieniak, A. Szymczakowa, red. A. Gassiorowski, Wrocław 1985.

Witczak T., Lasocki Mikołaj h. Dołega, [w:] Polski słownik biograficzny, t. XVI, Wrocław 1971, s. 542-544.

Zdanek M., Minoga, [w:] Słownik historyczno-geograficzny województwa krakowskiego w średniowieczu, oprac. W. Bukowski, J. Laberschek, A. Marzec, M. Wolski, M. Zdanek, współpraca archeologiczna S. Kołodziejski, red. W. Bukowski, cz. 4, z. 3, Kraków 2009, s. 483-499.

\section{Netografia}

Materiały do Kodeksu Dyplomatycznego Małopolski, t. V (1451-1506), edycja elektroniczna, oprac. W. Bukowski, F. Sikora, J. Wroniszewski, red. W. Bukowski, przy współpracy J. Szyszki, http://www.kodeks.pau.krakow.pl/dokumenty. html (dostęp: 20 I 2020).

\section{ANEKS 1}

Zapisy na dobrach królewskich dla Michała Lasockiego

\begin{tabular}{|l|l|l|l|l|}
\hline \multicolumn{1}{|c|}{ Miejsce } & \multicolumn{1}{|c|}{ Data } & \multicolumn{1}{|c|}{ Kwota } & $\begin{array}{c}\text { Królew- } \\
\text { szczyzna }\end{array}$ & \multicolumn{1}{c|}{ Źródło } \\
\hline Buda & 1 X 1442 & 200 grz. & Śrem & $\begin{array}{l}\text { CDP, t. I, nr 182; } \\
\text { KDW, t. X, nr 1596 }\end{array}$ \\
\hline Buda & 11 XII* $1442^{*}$ & $\begin{array}{l}400 \text { grz. } \\
\text { i 400 fl. (za- } \\
\text { pis powięk- } \\
\text { szony łącznie } \\
\text { do 610 grz. } \\
\text { i 400 fl.) }\end{array}$ & Śrem & Inventarium..., s. 283 \\
\hline
\end{tabular}


Michał Lasocki (zm. 1472) - konfederat, rycerz, polityk...

\begin{tabular}{|c|c|c|c|c|}
\hline Miejsce & Data & Kwota & $\begin{array}{l}\text { Królew- } \\
\text { szczyzna }\end{array}$ & Źródło \\
\hline Buda & 23 VI 1443 & 400 grz. & Śrem & Invenatrium..., s. 284 \\
\hline Csepel & $10 \mathrm{~V} 1444$ & 1000 grz. & Żydaczów & ZDM, cz. 8, nr 2480 \\
\hline Łęczyca & 31 I 1455 & 200 grz. & Śrem & Inventarium..., s. 285 \\
\hline Brześć Kuj. & 25 VI 1456 & 100 grz. & $\begin{array}{l}\text { Błonie } \\
\text { (sołectwo) }\end{array}$ & MRPS I, nr 310 \\
\hline Brześć Kuj. & 25 VI 1456 & 100 grz. & Śrem & MRPS I, nr 311 \\
\hline Łęczyca & 21 IX 1457 & 300 grz. & Śrem & $\begin{array}{l}\text { Inventarium..., s. 285; } \\
\text { G. Rutkowska, Itine- } \\
\text { rarium..., s. } 160\end{array}$ \\
\hline Łęczyca & 30 VIII 1459 & 130 fl. węg. & Śrem & MRPS I, nr 529 \\
\hline Łęczyca & 30 VIII 1459 & 100 fl. węg. & Śrem & MRPS I, nr 530 \\
\hline $\begin{array}{l}\text { Piotrków } \\
\text { (na sejmie) }\end{array}$ & 18 XII 1459 & 100 fl. węg. & Śrem & MRPS I, nr 539 \\
\hline Radom & 30 XI 1461 & 50 grz. & Śrem & $\begin{array}{l}\text { Inventarium..., s. } 287 \\
\text { (brak daty dziennej); } \\
\text { A. Ga siorow ski, } \\
\text { Starostowie..., s. } 64 ; \\
\text { G. Rutkow ka, Itine- } \\
\text { rarium..., s. } 183\end{array}$ \\
\hline Poznań & 7 VI 1462 & 100 grz. & Śrem & $\begin{array}{l}\text { Inventarium..., s. } 287 \\
\text { G. Rutkow s ka, Itine- } \\
\text { rarium..., s. } 187\end{array}$ \\
\hline $\begin{array}{l}\text { Piotrków } \\
\text { (na sejmie) }\end{array}$ & 28 I 1463 & 100 grz. & Śrem & $\begin{array}{l}\text { Inventarium..., s. 286; } \\
\text { A. Ga si or ow ski, } \\
\text { Starostowie..., s. 64; } \\
\text { G. Rutkow k k, } \\
\text { Itinerarium..., s. } 192 \text {, } \\
\text { przyp. } 963\end{array}$ \\
\hline $\begin{array}{l}\text { Piotrków } \\
\text { (na sejmie) }\end{array}$ & 2 XII 1469 & 50 grz. & Wiączyn & $\begin{array}{l}\text { MRPS II, nr } 86 \\
\text { (Suplement) }\end{array}$ \\
\hline Kraków & 9 VIII 1471 & 200 grz. & Wiączyn & $\begin{array}{l}\text { MRPS II, nr } 88 \\
\text { (Suplement) }\end{array}$ \\
\hline
\end{tabular}

* W przywołanym źródle znajduje się następująco zapisana data: „feria tertia infra octavas B.V. Mariae, anno 1442". W naszym przekonaniu - mimo braku precyzyjnie podanego święta maryjnego - w grę może wchodzić święto Niepokalanego Poczęcia NMP, które przypada na 8 XII. W dokumencie czytamy bowiem o zgodzie 
króla na wykup Śremu z rąk Wincentego z Szamotuł, kasztelana międzyrzeckiego, przez Michała Lasockiego i powiększeniu dotychczasowych sum za służbę na Węgrzech. Pierwszy znany nam zapis na Śremie na rzecz Lasockiego pochodzi z 1 X 1442 r., a najbliższe święto NMP przypadające po tej dacie miesięcznej, ale mieszczace się jeszcze w tym samym roku, to wspomniane Niepokalane Poczęcie NMP. Zatem, rozwiązując datę, proponujemy 11 XII 1442 r., którą zdaje się, można utrzymać, gdyż wiadomo, że Władysław Warneńczyk przebywał w Budzie 6 XII, a dopiero 14/15 XII odnotowano jego pobyt w Györ. Por. S.A. Sroka, W. Zawitkowska, op. cit., s. 87 oraz przyp. 115.

Źródło: opracowanie własne.

\section{ANEKS 2}

Uproszczona tablica genealogiczna Lasockich herbu Dołęga w XV-XVI w.

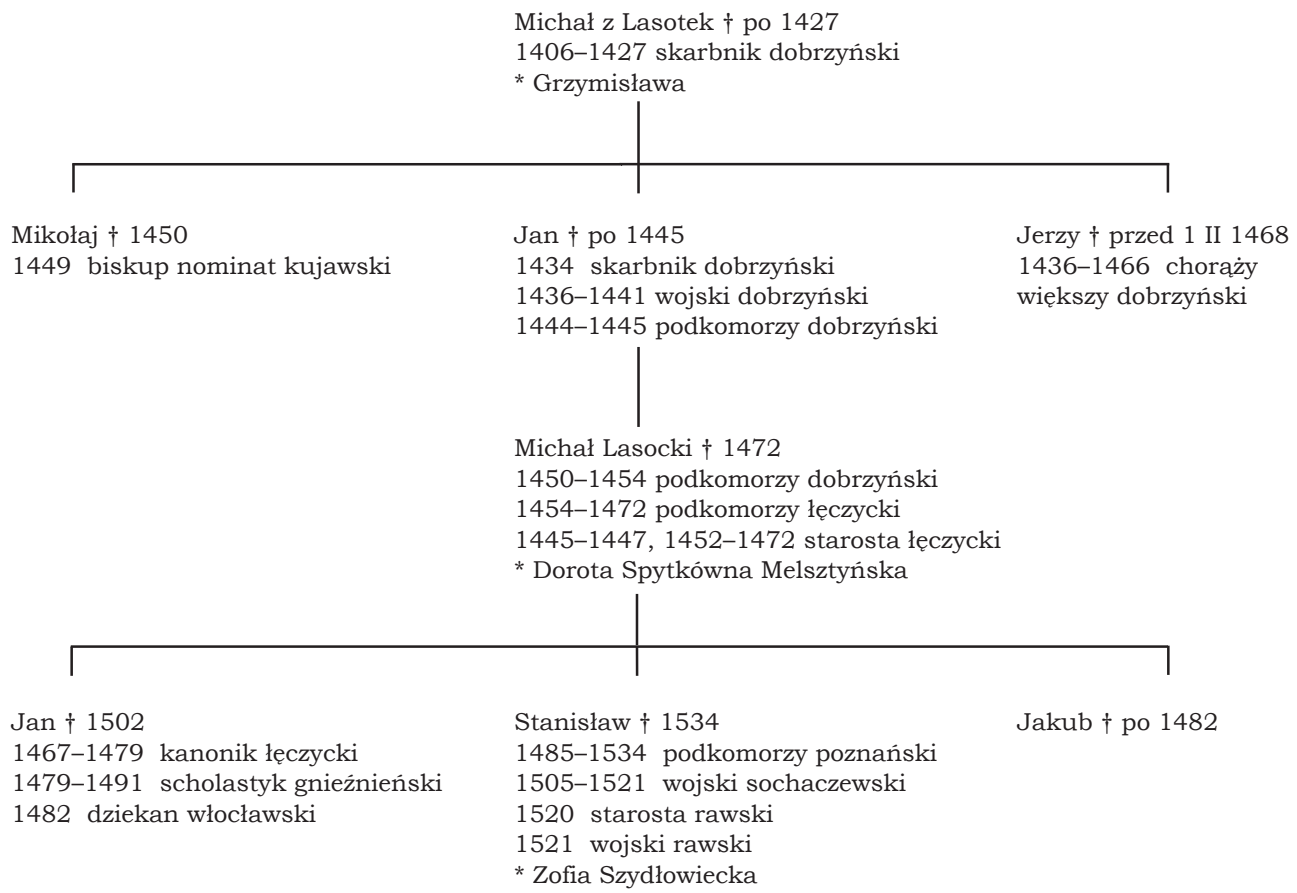

Źródło: opracowanie własne. 
ŁUKASZ ĆWIKŁa

UNIVERSITY OF LODZ

\section{Michael Lasocki (died 1472) - confederate, knight, politician. Contribution to the research on the signatories of Spytko's of Melsztyn confederation in 1439}

\footnotetext{
This article is an attempt to meet Franciszek Sikora's demand for research into 1 the careers of former confederates of Spytek of Melsztyn in 1439. The title hero belonged to Spytek's fraction, then he took part in the Hungarian expedition of Wladislaus of Varna, and during the reign of Casimirus Jagiellonian his political career accelerated. Thanks to the favor of the rulers, he received endowments of royal property, took over the Łęczyca starosty, reached for land offices and finally got to the royal court. As the court marshal, he joined the group of the political elite of the Kingdom.
}

Keywords: Michael Lasocki coat of arms Dołęga, nobility, the confederation of Spytek of Melsztyn. 